\title{
Gerakan Puritanisme Persatuan Islam di Kepulauan Sapeken- Sumenep Madura, 1972-2016
}

\author{
Nurul Fatimah \\ nurulmunadi93@gmail.com
}

\begin{abstract}
This study focuses on the discussion of puritanisme movement in Sapeken islands SumenepMadura. As it is known that the area of Madura is a very loyal tradisional Islamic support base. But especially in the Sapeken islands, the puritanical Islamic can actually thrive. The purpose of this study is to know the process of development of the puritanitanism movement (Persis). This study also attempts to answer the question of why puritanical islamic is capable of developing in the Sapeken islands. Using the protestant ethic of Max Weber, it can be seen that the entry of the puritanism movement (Persis) is base on the socio-religious conditions of society which are still considered far from the pure Islamic teachings. Therefore (Persis) perform purification of tradisional Islamic traditions and lokal art that still contains elements of takhayul, bid'ah dan khurafat, with the aim of returing the ummah to the teachings of the qur'an and sunnah. Throgh education institutions, Persis instilling a puritan ideology to the people, in addition, Persis in the Sapeken islands became more dominant religious organization, evident from the development of more rapid educational institutions due to the high work ethic of puritan muslims (Persis).
\end{abstract}

Keywords: Puritanism, Persis, Sapeken Islands.

\begin{abstract}
Abstrak
Studi ini fokus pada bahasan gerakan puritanisme di kepulauan Sapeken SumenepMadura. Seperti yang diketahui bahwa wilayah Madura merupakan basis pendukung Islam tradisional yang sangat loyal. Tetapi secara khusus di kepulauan Sapeken, Islam puritan justru dapat berkembang pesat. Tujuan dari studi ini adalah untuk mengetahui proses perkembangan gerakan puritanisme Persatuan Islam (Persis). Studi ini juga berusaha menjawab pertanyaan mengapa Islam puritan mampu berkembang di kepulauan Sapeken. Dengan menggunakan teori etika protestan Max Weber, dapat dilihat bahwa masuknya gerakan puritanisme (Persis) didasarkan pada kondisi sosial keagamaan masyarakat yang dinilai masih jauh dari ajaran Islam yang murni. Oleh sebab itu Persis melakukan purifikasi terhadap tradisi Islam tradisional dan kesenian lokal yang masih mengandung unsur-unsur takhayul, bid ah dan khurafat dengan tujuan mengembalikan umat kepada ajaran al-Quran dan Sunnah. Melalui lembaga pendidikan, Persis mampu menanamkan ideologi puritan kepada masyarakat. Selain itu, Persis di kepulauan Sapeken menjadi organisasi keagamaan yang lebih dominan, terlihat dari lembaga pendidikan yang lebih pesat karena etos kerja yang tinggi dari muslim puritan Persis.
\end{abstract}

Kata Kunci: Puritanisme, Persis, Kepulauan Sapeken

\section{PENDAHULUAN}

Secara umum gerakan pembaruan Islam diawali sekitar abad ke-19, di Indonesia sendiri ditandai dengan berdirinya berbagai organisasi sosial keagamaan seperti Jamiat Khaer, Sarekat Islam, Muhammadiyah, Nahdlatul 
Ulama dan Persatuan Islam. ${ }^{1}$ Orientasi dari gerakan pembaruan tersebut adalah mengembalikan umat kepada al-Qur`an dan Sunah. Dalam hal ini Persatuan Islam (Persis) juga memiliki orientasi yang demikian, organisasi yang didirikan oleh KH. Zamzam dan KH. Muhammad Yunus pada 12 September 1923 di Bandung, ${ }^{2}$ memiliki perjuangan yang gigih dalam melakukan gerakan pemurnian agama yakni dengan cara "Purifikasi" atau pemurnian akidah, ibadah dan akhlak umat dari syirik, takhayul, khurafat, bid ah dan munkarat. Usaha purifikasi yang dilakukan Persis bukan perkara yang mudah untuk dilakukan karena, persoalan ini sangat sensitif dalam masyarakat yang nantinya dapat mengakibatkan reaksi yang cukup keras bahkan Persis tidak jarang dianggap sebagai agama baru yang akan memecah persatuan umat. ${ }^{3}$ Faktor inilah yang dapat menyebabkan Persis di masyarakat kepulauan sulit untuk berkembang pesat karena, syirik, takhayul, khurafat, bid ah dan munkarat merupakan bagian dari tradisi dalam kehidupan nelayan yang mendominasi sebagaian masyarakat. Kepulauan Sapeken ${ }^{4}$ adalah salah satu daerah yang menjadi pusat gerakan puritanisme Persis di Madura.

Secara umum masyarakat Madura identik dengan daerah yang mayoritas masyarakatnya memiliki dukungan terhadap paham Islam tradisional ${ }^{5}$ yang diinterpretasikan dari organisasi keagamaan Nahdlatul Ulama. Mengingat bahwa antara paham Islam tradisional dan paham Islam puritan saling bertolak belakang maka gerakan puritanisme Persis tidak mudah masuk di wilayah Madura. ${ }^{6}$ Posisi saling bertolak belakang tersebut didasarkan pada perbedaan pandangan mengenai budaya dalam Islam. Paham Islam

1Deliar Noer, Gerakan Modern Islam di Indonesia 1900-1942 (Jakarta: LP3ES, 1980), 1. Lihat juga Dadan Wildan, Pasang Surut gerakan pembaharuan Islam di Indonesia Potret Perjalanan Sejarah Organisasi Islam (Persis) (Bandung: Persis Press, 2000), 20-25.

${ }^{2}$ Bandung terlihat lamban dalam rangka melakukan gerakan pembaharuan Islam jika di bandingkan dengan daerah-daerah lain, pada hal cabang Sarekat Islam sudah berdiri sejak 1913 di kota Bandung. Kesadaran atas keterlambatan itu merupakan sebuah inspirasi untuk mendirikan organisasi baru. Dadan Wildan, "Pergulatan Persatuan Islam (Persis) dalam Dakwah di Tatar Sunda: Kajian Terhadap Majalah Sunda "Iber" Sebagai Media Dakwah Berbahasa Sunda". Paper dipresentasikan dalam acara Konferensi Internasional Budaya Sunda II, Revitalisasi Budaya Sunda: Peluang dan Tantangan dalam Dunia Global di Gedung Merdeka, 19-22 Desember 2011, 3.

${ }^{3}$ Dadan Wildan, Pasang Surut gerakan pembaharuan Islam di Indonesia Potret Perjalanan Sejarah Organisasi Islam (Persis), 25.

${ }^{4}$ Kepulauan Sapeken merupakan bagian dari wilayah Madura, yang terletak dalam satu gugusan kepulauan Kangean dan merupakan bagian dari kabupaten Sumenep Jawa Timur. Dengan batas sebelah utara Laut Jawa, sebelah timur Laut Jawa atau Flores, sebelah selatan Selat Madura dan sebelah Barat Kabupaten Pamekasan. Lihat Badan Pusat Statistik Kabupaten Sumenep, Kabupaten Sumenep Dalam Angka Tahun 2009 (Sumenep: BPS, 2009), hlm. 2.

${ }^{5}$ Islam tradisional adalah Islam yang masih terikat kuat dengan pikiran-pikiran para "ulama" ahli fiqh (hukum Islam), hadis, tafsir, tauhid (teologi Islam) dan tasawwuf yang hidup antara abad ke-7 sampai dengan abad ke-13. Zamakhsyari Dhofier, Tradisi Pesantren Studi Tentang Pandangan Hidup kyai (Jakarta:LP3ES,1982), 1.

${ }^{6}$ Nurul Fatimah, "Pesantren Sebagai Basis Pengembangan Islam Puritan di kepulauan Madura (Studi Kasus Pondok Pesantren Persatuan Islam Abu Hurairah di Pulau SapekenSumenep Madura)" , Kurikula Jurnal Pendidikan, Fakultas Tarbiyah Institut Agama Islam Ngawi, Vol 1, No. 1, Maret 2017, 10. 
puritan memiliki pandangan bahwa Islam harus dibersihkan dari segala bentuk pengaruh luar (termasuk budaya sinkretis) dan bentuk keyakinan dan praktik keagamaan. Sebaliknya paham Islam tradisional memandang budaya sebagai sarana berlangsungnya transformasi agama. Mereka menganggap ajaran Islam sudah merupakan bagian dari budaya mereka bahkan perilaku keagamaan mereka banyak diekspresikan melalui tradisi yang sudah membudaya, di samping perilaku formal agama dan juga ibadah. ${ }^{7}$ Dua paham keagamaan yang berbeda merupakan suatu tantangan terhadap masuk dan berkembangnya Persis di Kepulauan Sapeken. Bahkan purifikasi yang dilakukan Persis terhadap tradisi kegamaan Islam tradisional dan tradisi lokal di kepulauan Sapeken juga menimbulkan konflik yang tidak hanya dalam ranah pemikiran tetapi juga konflik secara fisik. Meski demikian gerakan puritanisme Persis pada akhirnya mampu bertahan dan berkembang hingga sekarang. Dari uraian di atas, studi ini dimaksudkan untuk menjawab pertanyaan bagaimana islam puritan Persis mampu berkembang di kepulauan?

Untuk menganalisis studi tentang masuknya gerakan puritanisme Persis di Kepulauan Sapeken, peneliti meminjam teori yang dicetuskan oleh Max Weber tentang etika protestan. Sebagaimana studi yang telah dilakukan oleh James L. Peacock tentang ajaran puritan, konsepsi Peacock dalam hal ini mengatakan bahwa ajaran puritan didasarkan kepada ajaran pembaruan Islam, yang kasusnya mirip dengan ajaran Kristen Protestan. ${ }^{8}$ Para pembaru lebih memilih kembali kepada ajaran yang murni yang tertulis dalam al-Qur`an dan Sunah, dibandingkan harus taklid kepada hasil penafsiran para ulama dan kiai. Jika Peacock menjadikan Muslim puritan Muhammadiyah sebagai objek, dalam studi ini peneliti lebih memfokuskan kepada Muslim puritan Persis. Gerakan puritanisme Islam dalam beberapa hal terdapat kesamaan dengan doktrin Kristen Protestan Calvinis, ${ }^{9}$ dari lima alasan sebagaimana yang dikemukakan oleh Sukidi. ${ }^{10}$ Pertama, Calvinis dan Muslim puritan keduanya bersandar kepada ajaran kitab suci. Dalam Protestan Calvinis terdapat doktrin Sola Scriptura (kembali ke Al-kitab) sedangkan dalam doktrin Persis terdapat doktrin kembali kepada al-Qur`an dan sunah.

Kedua, etika dalam berdoa sebagai konsekuensi dari doktrin kembali ke ajaran kitab suci yaitu tidak adanya perantara untuk berdoa melainkan berdoa langsung kepada Tuhan.Dalam hal ini Calvinis memiliki doktrin Sola Fide (hanya karena iman orang bisa selamat) di samping itu Calvinis jugamerubah unsur sakramen serta menolak sistem hierarkis gereja. Sama halnya dengan Muslim puritan Persis yang menganggap tidak ada sesuatu yang menjadi

${ }^{7} \mathrm{M}$ Alfandi, "Prasangka Potensi Pemicu Konflik Internal Umat Islam, Walisongo, IAIN Walisongo Semarang, Vol. 21, No. 1, Mei 2013, 2.

8James L. Peacock. Muslim Puritans: Reformist Psycology in South East Asia (Berkeley: universityof California Press, 1978), 4-8.

9Sutiyono, Benturan Budaya Islam: Puritan dan Sinkretis, 52-53. Dikutip dari Eddy Kristiyatno, Reformasi dari Dalam: Sejarah Gereja Zaman Modern (Yogyakarta: Kanisius, 2004), 7182.

${ }^{10}$ Sukidi, "Etika Protestan Muslim Puritan: Muhammadiyah Sebagai Reformasi Islam model Protestan", Kompas, 1 Juni 2005. 
perantara dalam berdoa, dalam arti lain tidak ada perantara atau mediasi antara manusia dengan Tuhan. Hubungan antara Tuhan dan manusia menjadi tanggung jawab individu masing-masing. Ketiga, sebagaimana konsepsi yang dinyatakan Max Weber yaitu disenchanment of the world, kaum Calvinis ${ }^{11}$ dan puritan Persis mengikuti pandangan tersebut. Kebangkitan Persis merupakan sebuah respons dari adanya bid 'ah, takhayul, khurafat, syirik, musyrik, dan taklid buta. Sesuai dengan tesis Weber bahwa segala bentuk yang nonrasional dan bentuk unsur magis harus dihilangkan dari Muslim puritan dan konsepsi keduniaan. Secara tidak langsung Muslim puritan berorientasi pada dua tujuan yaitu ekslusi unsur-unsur magis dari ajaran Islam dan demistifikasi konsepsi duniadengan cara mendasarkan pada kalkulasi rasional dan hidup asketis di dunia. Keempat, merupakan suatu bentuk konsekuensi dari konsepsi disenchanment of the world, Muslim puritan memiliki kemiripan denganCalvinis tentang konsep rasionalisasi.

Persis melakukan rasionalisasi kepercayaan dengan jalan purifikasi terhadap tradisi-tradisi kegamaan yang dianggap tidak berlandaskan ajaran yang murni dan mengandung unsur-unsur mistis lainnya yang dikhawatirkan akan menjerumuskan manusia kepada kesyirikan. Adanya taklid buta kepada para ulama dan kiai berusaha dihilangkan dengan cara menanamkan tradisi berpikir kritis dan rasional melalui ijtihad, serta harus merujuk langsung kepada al-Qur'an dan sunah.Semangat rasional sebagai sebuah bentuk kemajuan bagi umat Islam dalam dunia moden. Kelima, baik Calvinis maupun Muslim puritan mengadopsi konsepsi yang disebut Max Weber sebagai "innerworldy asceticism". Protestan asketis, Calvinis memakai metode asketis untuk mengubah dunia. Spirit kapitalisme muncul dari proses "afinitas elektif" antara disiplin diri kalangan Calvinis dan asketisisme. Begitu jugaMuslim puritan juga mengadopsi asketisisme dunia dengan tasawuf modern tanpa melarikan diri dari kehidupan dunia. Konsep-konsep Max Weber di atas yang digunakan peneliti sebagai pisau analisis dalam menjawab permasalahanpermasalahan dalam kajian ini.

\section{HASIL DAN PEMBAHASAN}

\section{Tradisi Kegamaan Masyarakat Kepulauan Sapeken}

Masyarakat kepulauan Sapeken umumnya memiliki kepercaya bahwa laut adalah segalanya. Kehidupan mereka bergantung pada laut, mereka juga memiliki kepercayaan bahwa dewa mereka bersemayam di lautan yang mereka sebut Mbo Ma Dilao atau dewa laut. Mereka percaya Mbo Ma Dilao berjumlah

\footnotetext{
11Proses historis perkembangan agama, penghilangan kekuatan magis dari dunia telah dimulai sejak para nabi Ibrani dan pemikiran Yunani Kuno. Kaum puritan Calvinis menghilangkan semua sarana magis untuk mencapai keselamatan sebagai sebuah takhayul dan dosa. Bahkan kaum Calvinis puritan sejati menolak semua tanda tanda upacara keagamaan di kuburan, tidak mengubur orang orang terkasih dengan pujian atau upacara ritual supaya terhindar dari takhayul dan tidak ada unsur unsur magis dan sakramental pada keselamatan yang menyusup di dalamnya. Max Weber, Etika Protestan dan Spirit Kapitalisme, TW Utomo dan Yusup Priya Sudiarja (terj.) (Yogyakarta: Pustaka Pelajar, 2006), 94.
} 
empat yakni Mbo janggo, Mbo Tambirah, Mbo Goyah dan Mbo Dugah. ${ }^{12}$ Penduduk asli kepulauan Sapeken adalah suku Bajo yang berasal dari Sulawesi Selatan. Sebagaimana tradisi masyarakat Bajo yang suka melaut dan hidup berpindah-pindah hal inilah yang membuat suku Bajo tersebar dibeberapa wilayah di Indonesia termasuk di wilayah kepulauan Sapeken-Sumenep Madura. Kepercayaan terhadap dewa laut masih diadobsi masyarakat Bajo meski sudah memeluk agama Islam. Hal ini dapat tercermin dari tradisi mereka seperti melakukan ritual dengan berbagai macam sesaji sebelum melaut tujuannya adalah memohon kepada Sang penguasa laut agar diberikan hasil tangkapan ikan yang banyak serta dapat terhindar dari mara bahaya selama berada di laut. Tradisi lain yang masih ada hubungannya dengan penguasa laut adalah tradisi slametan jalan (slamatan yang diadakan di jalan), tradisi ini dipercaya dapat mengembalikan roh-roh jahat yang berasal dari laut yang mengganggu manusia, dipercaya akan kembali ketempat asalnya. Upacara slametan desa juga di anggap sebagai sesuatu yang harus dilakukan di setiap tahun dengan tujuan menolak bala di desa-desa yang mereka tinggali. Kepercayaan semacam ini bagi kaum putitan dianggap sebagai sesuatu yang bertentangan dengan Islam karena dinilai mengandung unsur-unsur takhayul, bid ah dan khurafat. Tetapi bagi masyarakat Bajo tradisi-tradisi tersbebut dapat menjadi media untuk saling merekatkan tali persaudaraan di antara mereka. ${ }^{13}$

\section{Gerakan Sosial Keagamaan di Kepulauan Sapeken}

Gerakan sosial keagamaan di Indonesia dimulai sejak awal abad ke-20, termasuk berdirinya dua organisasi terbesar di Indonesia yaitu Nahdlatul Ulama dan Muhammadiyah. Kedua organisasi ini cukup memberikan gambaran bahwa di Indonesia telah diwarnai dua paham keagamaan yang saling bertolak belakang yaitu islam tradisionalis dan islam puritan. Begitu juga di dalam lingkup yang lebih khusus yakni di kepulauan Sapeken yang juga di warnai oleh dua paham keagamaan tersebut tetapi yang membedakan adalah terdapat dinamika yang signifikan mengenai pengaruh atau dominasi organisasi Islam puritan dan Islam tradisional terhadap masyarakat di kepulauan Sapeken.

1) Islam Tradisional

Gerakan Islam tradisional muncul pada tahun 1930 yang dibawa oleh KH. Abu Hurairah (w.1974), yang berasal dari Pambauwang mandar, Makassar Sulawesi Selatan. KH. Abu Hurairah sempat melakukan perjalanan ke beberapa negara tetangga yaitu Filipina, malaysia dan Singapura untuk tujuan berdagang disamping juga berdakwah. KH. Abu Hurairah juga pernah melakukan perjalanan ke Makkah bersama dengan ayahnya untuk berhaji serta menuntut ilmu. Selama kurang lebih sepuluh tahun KH. Abu Hurairah berguru kepada syeh-syeh yang mengajar di masjid al-Haram. KH. Abu Hurairah juga pernah berguru dari ulama yang berasal dari Sulawesi yang juga sebagai mufti di

12Baskara, Benny Islam Bajo Agama Laut (Banten: Javanica PT Kaurama Buana Antara. 2016), 158.

13Ibid., 201. 
kerajaan Bone yang ke-12 dan juga menjadi mertua dari $\mathrm{KH}$ Abu Hurairah sendiri yaitu KH. Abdul Wahid.Selain itu ia juga berguru kepada para ulama yang datang dari Makkah dan Madinah seperti KH. Abdurrauf dan Muhammad Shaleh al-Yamani. ${ }^{14}$ Paham Islam tradisional tersalurkan melalui kelompok pengajian dan taklim di kalangan masyarakat kepulauan Sapeken yang di bentuk oleh $\mathrm{KH}$. Abu Hurairah. Jamaah dalam pengajian tersebut tidak hanya masyarakat setempat tetapi banyak juga yang berasal dari luar kepulauan Sapeken seperti pulau Lombok, Sumbawa, Flores, dan Sulawesi. Pemahaman tentang Islam tradisional dianjarkan oleh KH. Abu Hurairah dengan mengambil sumber dari kitab-kitab klasik, salah satunya adalah kitab al-Umm karya imam Syafi i. Kelompok pengajian dan taklim yang di bentuk oleh KH. Abu Hurairah merupakan embrio dari pendidikan formal maupun non formal dikepulauan Sapeken. ${ }^{15}$ Paham Islam tradisional mudah diterima oleh hampir semua lapisan masyarakat kepulauan Sapeken karena metode dakwah yang dilakukan oleh KH. Abu Hurairah terkesan lentur dan masih mentolelir tradisi dan kebudayaan asli masyarakat suku Bajo ${ }^{16}$ di kepulauan Sapeken. ${ }^{17}$

\section{2) Tiga Gelombang Gerakan Puritanisme}

Setelah gerakan keagamaan yang dibawa oleh KH. Abu Hurairah berkembang luas di seluruh kepulauan Sapeken, kemudian pada 1949 muncul gerakan puritanisme Persatuan Islam (Persis) yang dibawa oleh seorang pegawai negeri yang bekerja di kecamatan Sapeken bernama H. Sahwanuddin dari pulau Kangean.H. Sahwanuddin memiliki kontak dengan sejumlah pimpinan organisasi Persatuan Islam di Bandung, dia juga berlangganan majalah-majalah terbitan Persis. Di samping menjalankan tugas sebagai pegawai $H$. Sahwanuddin juga melakukan penyebaran paham Islam puritan, melalui pengajian al-Qur’an yang diadakannya. Tidak banyak yang mengikuti ajaran Islam puritan yang masih dianggap baru di kalangan masyarakat Sapeken, $\mathrm{H}$. Sahwanuddin hanya memiliki dua murid yang mengikuti paham yang diajarkannya, yaitu wak Arit dan wak Sahabat, bersama kedua muridnya tersebut H. Sahwanuddin mengembangkan paham Islam puritan.

Selanjutnya pada 1953 Ahmad Bajuri yang merupakan murid dari Ahmad Hassan dan berstatus sebagai bendahara Pesantren Persatuan Islam

${ }^{14}$ Wawancara dengan ustaz Ad-Dailamy Abu Hurairah, Rabu 25 April 2017.

${ }^{15}$ M. Bahri Ghazali, Dakwah di kepulauan Kasus Pondok Pesantren Persatuan Islam Abu Hurairah Sapeken Sumenep (Yogyakarta: CV Amanah, 2011), 38.

16Penduduk asli yang menempati kepulauan Sapeken adalah orang-orang suku Bajo yang berasal dari Makassar hal ini didasarkan pada cerita turun temurun yang beredar di kalangan masyarakat Bajo Sapeken. Fakta lain yang menjadi bukti bahwa mereka adalah keturunan suku Bajo dapat dilihat dari bahasa yang mereka gunakan sehari-hari yaitu bahasa Bajo bukan bahasa Madura mengingat bahwa wilayah kepulauan Sapeken termasuk bagian dari Madura. Hasil wawancara dengan H. Benu, salah satu tokoh masyarakat Sapeken, pada 30 Januari 2017.

${ }^{17}$ Nurul Fatimah, "Pesantren Sebagai Basis Pengembangan Islam Puritan di kepulauan Madura (Studi Kasus Pondok Pesantren Persatuan Islam Abu Hurairah di Pulau SapekenSumenep Madura)", 14. 
Bangil, datang ke Sapeken untuk tujuan dakwah dan dagang. Ahmad Bajuri sempat menikah dengan gadis Sapeken yang bernama Supini dan dikaruniai dua orang anak Muhammad Ghazali dan Baihaqi, yang sampai sekarang keduanya masih menjadi pengajar di Pesantren Persis Bangil. Dakwah yang dibawa oleh Ahmad Bajuri juga belum mendapatkan respons yang baik dari masyarakat Sapeken hingga tahun 1967. Kemudian pada 1962 datang lagi seorang tokoh Islam puritan dari Muhammadiyah bernama H. Jamal Sulaiman dari Watampone Bugis Sulawesi Selatan, yang bermaksud untuk mencari keluarganya di pulau Sapeken, yang tidak lain keluarga yang dimaksud adalah KH. Abu Hurairah. Oleh keluarganya, Jamal Sulaiman diminta untuk menetap di pulau Sapeken, dari situ Jamal Sulaiman berkesempatan untuk melakukan dakwah dan menyebarkan paham Islam puritan di Sapeken. ${ }^{18}$ Jamal Sulaiman adalah tokoh yang pertama memperkenalkan Islam puritan Muhammadiyah di Sapeken.

Ketiga tokoh tersebut adalah yang mengawali gerakan puritanisme Islam di pulau Sapeken. ${ }^{19}$ Gerakan puritanisme yang dilakukan oleh ketiga tokoh tersebut tidak lain seperti yang dilakukan oleh KH. Abu Hurairah yakni melalui majlis taklim. Selain itu, para tokoh pembaru tersebut memberikan beasiswa kepada anak-anak para tokoh masyarakat yang berpengaruh saat itu, termasuk anak-anak yang disekolahkan pada waktu itu adalah putra $\mathrm{KH}$. Abu Hurairah sendiri, yaitu KH. Ad-Dailamy Abu Hurairah, H. Muhammad Ali putra Daeng Sandrek yang merupakan kepala desa Sapeken, H. Natsir putra H. Abdul Ghani, dan lainnya. Kebanyakan anak-anak tersebut disekolahkan di pesantren-pesantren pembaruan seperti pesantren Persis dan Muhammadiyah.

Oleh karena, gerakan puritanisme yang dibawa oleh para tokoh Persis maupun Muhammadiyah kurang mendapatkan respons yang baik dari masyarakat, maka pada 1970-an ustaz Ad-Dailamy Abu Hurairah dan H. Ali bekerjasama, sehingga mampu melakukan penyebaran dan pengembangan Islam puritan melalui organisasi Persatuan Islam (Persis). Dari usaha yang mereka lakukan, ideologi Islam puritan dapat diterima dan mampu menggeser eksistensi Ideologi Islam tradisional yang lebih dulu dikenal oleh kalangan masyarakat pulau Sapeken. ${ }^{20}$ Gerakan puritanisme di Sapeken dapat dikatakan sudah memiliki pengaruh yang luas setelah melewati tiga gelombang yang pertama adalah 1949-1967 gerakan puritanisme Persis yang dibawa oleh H. Sahwanuddin dan Ahmad Bajuri, 1967-1972 gerakan puritanisme Muhammadiyah yang dibawa oleh H. Jamal Sulaiman dan 1972-sekarang gerakan puritanisme Persis yang dibawa oleh Ad-Dailamy Abu Hurairah.

\section{Persatuan Islam (Persis) dan Pemurnian Islam di Kepulauan Sapeken}

Gerakan puritanisme Persis hadir di tengah masyarakat kepulauan Sapeken berawal dari semangat dakwah ustaz Ad-Dailamy Abu Hurairah. Pengaruh

\footnotetext{
18Wawancara dengan ustaz Ad-Dailamy Abu Hurairah, Rabu 25 April 2017.

${ }^{19}$ Wawancara dengan ustaz Ad-Dailamy Abu Hurairah, Senin 6 Februari 2017.

${ }^{20}$ Wawancara dengan H. Ali, Pejabat pemerintah desa dan mantan kepala desa, Rabu 1 Februari 2017.
} 
Islam puritan didapatkannya dari Pesantren Persatuan Islam Bangil yang ketika itu dipimpin oleh Abdul Qadir Hassan (w.1984) putra dari Ahmad Hassan (w.1958) yang merupakan tokoh pendiri pesantren Persis Bangil. Ideologi Persis ditanamkan oleh Ad-Dailamy melalui pendidikan berbasis pesantren yang digagas sejak tahun 1973 dan diresmikan menjadi pesantren Abu Hurairah pada 1976. ${ }^{21}$ Nama pesantren tersebut diambil dari nama ayah dari Ad-dailamy yang menjadi tokoh Islam tradisionalis yang pertama kali menggagas embrio pendidikan Islam di kepulauan Sapeken. Dengan begitu terlihat bahwa Ad-Dailamy berusaha merubah ideologi tradisionalis menjadi puritan di dalam pendidikan yang ia bangun.

Perubahan ideologi pendidikan tersebut semakin terlihat setelah Persis secara organisatoris didirikan di kepulauan Sapeken pada 1991 oleh AdDailamy. Nama "Pesantren Abu Hurairah" di rubah menjadi "Pesantren Persis Abu Hurairah" sebagai tanda bahwa pesantren tersebut berada di bawah naungan organisasi Persis yang berpusat di Bandung. Bergabungnya pesantren Abu Hurairah menjadi bagian dari organisasi Persis tidak lain adalah karena keinginan Ad-Dailamy supaya pendidikan yang di bangunnya mempunyai tempat bernaung, sehingga tidak lagi menjadi lembaga pendidikan yang laksana terbuang di kepulauan terpencil, yang berjuang sendiri untuk tujuan menyebarkan paham Islam yang murni. Pada 1973-1991Pesantren Abu Hurairah secara independen berdiri dan menjadi media dakwah Ad-Dailamy untuk mengembalikan umat Islam kepada ajaran al-Qur`an dan Sunnah. Kurang lebih selama 18 tahun itulah Ad-Dailamy merasa sudah cukup mempunyai pendukung yang banyak sehingga ia berani menawarkan diri secara langsung kepada Pimpinan Persis Bandung untuk bergabung. ${ }^{22}$

Faktor utama yang melatar belakangi berdirinnya organisasi Persis di Sapeken tidak lain adalah persoalan realitas sosial keagamaan masyarakat kepulauan Sapeken yang masih bercampur dengan kepercayaan pra-Islam seperti animisme, dinamisme dan Hiduisme. Oleh sebab itu Persis hadir untuk tujuan menghilangkan praktik keagamaan yang demikian dengan cara melakukan gerakan purifikasi yakni memurnikan kembali ajaran Islam yang sesuai dengan sumber asli agama Islam yaitu al-Qur`an dan Sunnah. Persis berusaha melakukan purifikasi aqidah, ibadah dan akhlak umat Islam dari unsurunsur yang mengandung syirik, takhayul, bid ah dan khurafat. ${ }^{23}$ Cikal bakal gerakan puritanisme di kepulauan Sapeken sebelum Ad-Dailamy berkiprah sebagai tokoh puritan yaitu bermula dari program gerakan dakwah di kepulauan yang dilakukan Pesantren Persatuan Islam Bangil. Pada 26 Februari 1967 dengan dibentuknya Dewan Dakwah Islam Indonesia (DDII) oleh Muhammad Natsir, sehingga muncul gagasan program dakwah di kepulauan Nusantara. Sebelumnya kegiatan dakwah di kepulauan dilakukan oleh DDII

${ }^{21}$ Nurul Fatimah, "Pesantren Sebagai Basis Pengembangan Islam Puritan di kepulauan Madura (Studi Kasus Pondok Pesantren Persatuan Islam Abu Hurairah di Pulau SapekenSumenep Madura)", 15.

${ }^{22}$ Wawancara dengan ustaz Ad-Dailamy Abu Hurairah, Rabu 25 April 2017.

${ }^{23}$ Wawancara dengan ustaz Damin wakil ketua PC Persis Sapeken, Rabu 25 Januari

2017. 
dengan cara merekrut penduduk setempat kemudian diberikan pelatihan secara intensif di Jakarta, kegiatan perekrutan para pendakwah lokal itu dilakukan kurang lebih selama 5 tahun oleh DDII. Setelah 1972 Muhammad Natsir memberikan kepercayaan dan wewenang dalam menyiapkan tenaga pendakwah untuk melaksanakan dan melanjutkan program dakwah dikepulauan Nusantara tersebut, kepada Pesantren Persatuan Islam Bangil. Keputusan Muhammad Natsir untuk memberikan kepercayaan kepada Pesantren Persatuan Islam cukup beralasan karena yang pertama Muhammad Natsir sendiri adalah termasuk tokoh utama dalam gerakan organisasi PERSIS dan juga terdapat kedekatan emosional terhadap Ahmad Hassan selaku Penggagas Pesantren Pesatuan Islam, yang memang Muhammad Nastir adalah murid dari Ahmad Hassan. Kedua, pada 1972 Muhammad Natsir masih menjabat sebagai penasehat Pesantren Persatuan Islam Bangil. Ketiga, Pesantren Persatuan Islam Bangil termasuk salah satu pesantren yang menjadi basis penggodokan kader-kader pendakwah masa depan. Hal tersebut dapat dilihat dari metodenya dalam mendidik santri selama lima tahun secara intensif, sehingga pihak pesantren hanya menerima santri baru setiap lima tahun sekali. $^{24}$

Pengiriman para pendakwah jebolan Pesantren Persatuan Islam Bangil perdana, dilakukan dengan cara mengambil seluruh santri kelas akhir, angkatan tahun 1972. Para pendakwah Pesantren Persatuan Islam Bangil diberangkatkan ke kepulauan Sapeken untuk bertugas selama 20 hari. Program dakwah di kepulauan tersebut merupakan salah satu upaya yang dilakukan pesantren untuk menggembleng para santri supaya dapat terbiasa berdakwah di masyarakat dengan segala tantangan yang ada, sebelum melakukan tugas dakwah selama satu tahun di pulauyang berbeda dan dengan tantangan yang berbeda. ${ }^{25}$

Berawal dari program gerakan dakwah dikepulauan tersebut, misi gerakan puritanisme semakin kencang, terlebih lagi ketika Ad-Dailamy Abu Hurairah kembali dari Pesantren Persatuan Islam Bangil dan mulai berdakwah di pulau Sapeken. Ad-Dailamy segera melakukan usaha untuk mewujudkan visi misi organisasi Persis, yakni dengan cara melakukan gerakan puritanisme Islam, supaya segala bentuk peribadatan yang di lakukan oleh masyarakat Sapeken hanya berlandaskan pada al-Qur`an dan Sunah. Selama kurang lebih tiga tahun Ad-Dailamy berusaha untuk mendakwahkan paham Islam puritan di kalangan masyarakat Sapeken seorang diri tanpa seorangpun yang mendukung dan membantunya, sampai pada 1976 Ad-Dailamy meminta bantuan ke DDII supaya dikirimkan tenaga pendakwah untuk membantu melakukan gerakan puritanisme di pulau Sapeken. Para pendakwah yang dikirimkan oleh DDII ke kepulauan Sapeken diambil dari alumni-alumni yang berasal dari pesantren-pesantren yang berbasis paham puritan seperti alumni

${ }^{24}$ Ad-Dailamy Abu Hurairah, Peran L-PAS Abu Hurairah Dalam Dakwah di Kepulauan (Sumenep: Pesantren Persatuan Islam Abu Hurairah, 2015), 6.

${ }^{25}$ Ad-Dailamy Abu Hurairah, Peran L-PAS Abu Hurairah, 6. 
Pesantren Pesatuan Islam Bangil, Pesantren Muhammadiyah Karanganyar Paciran, Pesantren Ngruki Jawa Tengah, dan Pesantren di Salatiga. ${ }^{26}$

Fokus utama dalam dakwah Persis adalah melakukan purifikasi terhadap dua aspek yaitu purifikasi terhadap tradisi keagamaan Islam tradisional dan kesenian lokal yang dinilai tidak sesuai dengan syariat Islam. Beberapa tradisi Islam tradisional yang selalu menjadi sorotan bagi orangorang puritan adalah masalah slametan, tahlilan dan Maulid Nabi. Tradisi slametan sangat tegas ditolak oleh Persis karena mengandung unsur-unsur takhayul, bid ah dan khurafat. Berbagai upaya dilakukan supaya tradisi slametan tidak lagi di amalkan oleh masyarakat kepulauan Sapeken seperti memberikan penjelasan kepada masyarakat melalui pengajian-pengajian dan majlis taklim lainnya. Sedangkan tradisi tahlilan dan Maulid Nabi dianggap sebagai suatu yang bidah. Menurut paham Persis segala sesuatu yang bidah harus ditinggalkan. Menurut mereka tradisi tahlilan yang selama ini dilakukan sudah menyalahi niat karena Allah, karena biasanya tahlilan dilakukan untuk mendoakan orang yang sudah meninggal dengan menyuguhkan berbagai makanan kepada orang-orang yang datang ke rumah duka. Kalangan orangorang Persis meyakini bahwa memakan-makanan di rumah duka hukumnya haram karena akan semakin memberatkan yang ditinggalkan justru harusnya sebaliknya orang-orang yang datang ke rumah duka yang memberikan makanan. Atas dasar tersebut Persis melarang untuk tidak lagi melakukan tradisi tahlilan semacam itu. Tradisi Maulid Nabi juga tidak diperbolehkan karena Persis melarang mengkhususkan suatu ibadah pada hari-hari tertentu. ${ }^{27}$ Di samping itu, Persis juga melakukan purifikasi terhadap kesenian masyarakat kepulauan Sapeken seperti mengganti hiburan musik orkes yang di sertai dengan acara minum minuman keras dengan musik nasyid yang lebih bersifat Islami, menghilangkan seni tari Nigal yang mempertontonkan para wanita dengan pakaian terbuka sehingga dianggap sebagai suatu hiburan yang mengundang hawa nafsu para lelaki yang tidak sesuai dengan ajaran Islam ${ }^{28}$ dan meluruskan pemahaman yang dibawa seni beladiri silat tradisional yang banyak mengajarkan bahwa tenaga dalam berasal dari kekuatan magis dan mantra-mantra serta puasa sebagai syaratnya, menjadi seni beladiri pencak silat yang memberikan pemahaman bahwa kekuatan yang dihasilkan dari seni beladiri hanya bersumber dari Allah, yakni berasal dari kekuatan lahir dan batin manusia yang dihasilkan dari latihan secara sungguh-sungguh. Oleh karena itu muncullah seni bela diri silat Thifan di kepulauan Sapeken. ${ }^{29}$

Purifikasi yang dilakukan oleh Persis membutuhkan waktu yang tidak sedikit karena banyak orang-orang kepualuan Sapeken yang menentangnya. Perdebatan antara dua pendukung paham keagamaan tersebut sering terjadi hingga menimbulkan konflik yang tidak hanya dalam ranah pemikiran tetapi hingga konflik secara fisik. Sehingga menyebabkan Ad-Dailamy dijemput

\footnotetext{
26Wawancara dengan ustaz Ad-Dail.amy Abu Hurairah, Senin 1 Mei 2017.

27Wawancara dengan Fatmawati Rabu, 3 Mei 2017.

${ }^{28}$ Wawancara dengan ustaz Ad-Dailamy Abu Hurairah Senin, 1 Mei 2017.

${ }^{29}$ Wawancara dengan ustaz Ahmad, pelatih beladiri silat Thifan Jumat, 5 Mei 2017.
} 
paksa oleh aparat dan dipenjarakan pada 1 Maret 1975. Tantangan yang dialami oleh Ad-Dailamy sebagai tokoh utama Persis tidak hanya itu, ia juga sempat mendapatkan penganiayaan secara fisik dan tempat tinggalnya yang juga dijadikan tempat pengajian dibakar habis. Peristiwa tersebut tidak membuat Ad-Dailamy goyah dalam tujuannya, ia masih menghadapi tantangan yang datang dari para ulama yang belum bisa menerima paham keislaman yang dibawanya. Upaya Persis untuk meredam ketegangan yang terjadi adalah dengan melakukan dakwah secara persuasif, dengan menjelaskan bahwa paham yang ada diluar paham mereka tidak seharusnya dimusuhi, karena perbedaan paham mereka hanya tipis sekali. Dakwah dengan pendekatan persuasif tersebut bisa membuat paham puritan Persis sedikit demi sedikit bisa diterima oleh sebagian besar masyarakat kepulauan Sapeken.

Terdapat beberapa faktor yang menyebabkan Persis mampu bertahan bahkan berkembang pesat dikepulauan Sapeken. Pertama, tokoh pendiri Persis merupakan tokoh yang disegani dan berpengaruh di kalangan masyarakat, sebab Ad-Dailamy merupakan putra dari tokoh Islam tradisional yang sudah disegani sejak lama oleh masyarakat. Kedua, melakukan dakwah dengan pendekatan pribadi (personal approach), sehingga memberikan kesan bahwa Persis peduli dengan mereka. Tiga, menanamkan ideologi Islam puritan dari kalangan anak-anak sehingga paham tersebut tertanam kokoh dari dini, dan diharapkan anak-anak tersebut mampu menjadi generasi penerus Persis. Empat, didirikannya lembaga pendidikan pesantren yang menjadi cikal bakal berdirinya lembaga-lembaga pendidikan Islam di kepulauan Sapeken. Sehingga, sekarang Persis mampu mendirikan lembaga pendidikan dari pendidikan anak usia dini hingga sekolah tinggi. ${ }^{30}$

\section{Etos Kerja dan Asketisme Persis}

Konsepsi Max Weber mengemukakan bahwa agama memiliki pengaruh besar terhadap etos kerja yang dapat berpengaruh pada perkembangan ekonomi. Sebagaimana pemikiran Weber yang menyimpulkan bahwa diskursus keagamaan yang bersifat metafisik yang kemudian dikembangkan menjadi suatu ide asketisme yang sifatnya realistis. Disini dapat dilihat bahwa suatu tanda kesuksesan seorang manusia dalam kehidupan keagamaannya adalah ketika seseorang tersebut sukses di kehidupan dunianya. Weber juga mencetuskan istilah calling atau panggilan jiwa, yang diasumsikan sebagai cara untuk menumbuhkan motivasi yang melebihi perintah agama. ${ }^{31}$

Dalam hal ini ideologi Muslim puritan Persis juga memiliki pengaruh terhadap perkembangan ekonomi masyarakat Sapeken dan juga perkembangan Persis sendiri. Sebagaimana ajaran agama Islam yang didasarkan pada alQur`an dan sunah, mengatakan bahwa umat Islam dilarang untuk bermalasmalasan, karena hal tersebut dapat menyebabkan manusia menjadi lemah dan

\footnotetext{
${ }^{30}$ Wawancara dengan ustaz AD-Dailamy Abu Hurairah Senin, 1 Mei 2017.

${ }^{31}$ Nurkalis, "Positivikasi Asketisme dalam Islam Dengan Pendekatan Paradigma Klasik dan Modern," MIQAT, Fakultas ushuluddin dan Filsafat UIN Ar-Raniry., Vol. XXXIX No. 1 Januari-Juni 2015.
} 
dapat mendekatkan pada kekufuran. Selain itu, manusia yang suka bermalasmalasan tidak akan mendapatkan hasil yang maksimal dan hasil kerjanya bisa dipastikan tidak baik pula. Dengan doktrin yang demikian maka, umat Islam terdorong untuk menjadi manusia yang rajin dan bekerja keras. Selama ini Persis memiliki perhatian khusus dalam bidang pendidikan sebagai media untuk berdakwah dengan tujuan pengembangan ideologi puritannya di Sapeken.

Untuk mencapai tujuannya tersebut maka, perlu adanya dana sebagai modal untuk berdakwah. Dari sini, terdapat calling yang menumbuhkan etos kerja yang tinggi, untuk mendapatkan materi sebanyak-banyaknya. Oleh sebab itu, cara hidup yang sesuai dengan perintah agama yaitu dengan menumbuhkan etos kerja yang tinggi, untuk tujuan berdakwah dalam memperjuangakan risalah yang sesuai dengan ajaran al-Qur'an dan sunah. Sikap "asketisme duniawi" Islam puritan tercermin dalam pengabdian mereka kepada agama dengan cara menumbuhkan semangat kerja yang tinggi, sebagai sebuah bentuk dari perintah dalam agama Islam yang wajib dilakukan oleh mereka sebagai hamba Allah. Dengan begitu Muslim puritan Persis melakukan berbagai usaha perdagangan seperti mendirikan toko, rumah makan, pabrik, dan tempat persewaan alat pesta untuk mendapatkan materi sebanyak yang mereka inginkan.

Terdapat data empiris yang menunjukkan bahwa Muslim puritan Persis lebih mendominasi perekonomian Sapeken.

Tabel 1. Banyaknya Tempat Usaha Berdasarkan Organisasi Keagamaan ${ }^{32}$

\begin{tabular}{ccccc}
\hline Ormas & $\begin{array}{c}\text { Rumah } \\
\text { Makan }\end{array}$ & $\begin{array}{c}\text { Persewaan } \\
\text { Alat Pesta }\end{array}$ & Toko & Pabrik \\
\hline PERSIS & 8 & 4 & 33 & 2 \\
\hline NU & - & 1 & 7 & - \\
\hline Muhammadiyah & - & - & $\mathbf{4 2}$ & $\mathbf{2}$ \\
\hline Jumlah & $\mathbf{8}$ & $\mathbf{5}$ & \\
\hline
\end{tabular}

Sumber: Diolah dari berbagai sumber.

Etos kerja Muslim puritan Persis juga menjadi salah satu indikasi bahwa perkembangan Persis di Sapeken lebih pesat dibandingkan organisasi keagamaan yang lain (NU dan Muhammadiyah). Sebagian besar para pendukung Islam puritan Persis adalah sebagai pebisnis dan pejabat pemerintah desa. Dari usaha yang mereka jalankan, kemudian mereka mengumpulkan dana untuk pengembangan pendidikan dan sarana prasarana bagi kemaslahatan umat.

${ }^{32}$ Badan Pusat Statistik Kabupaten Sumenep, Kecamatan Sapeken Dalam Angka 2015 (Sumenep: BPS Kabupaten Sumenep, 2015), 84-85. Data ini diambil sebelum kelurahan Sapeken mengalami pemekaran pada 2016. 
Tabel 2. Banyaknya Lembaga Pendidikan Berdasarkan Organisasi Keagamaan

\begin{tabular}{cccccccc}
\hline Ormas & Tk & SD/MI & SMP/MTs & MA/MTs & $\begin{array}{c}\text { Perguruan } \\
\text { Tinggi }\end{array}$ & Madin & Ponpes \\
\hline Persis & 9 & 8 & 3 & 2 & 1 & 3 & 3 \\
\hline NU & 6 & 5 & 3 & 3 & - & 1 & 2 \\
\hline Muhammadiyah & 1 & 1 & 1 & - & - & - & - \\
\hline Jumlah & $\mathbf{1 6}$ & $\mathbf{1 4}$ & $\mathbf{7}$ & $\mathbf{5}$ & - & 3 & $\mathbf{5}$ \\
\hline
\end{tabular}

Sumber: Diolah dari berbagai sumber.

Dari kalkulasi jumlah lembaga pendidikan tersebut sudah mencerminkan bahwa Islam puritan Persis di Sapeken lebih dominan dibandingkan organisasi keagamaan NU dan Muhammadiyah. Selain diwujudkan dalam pengembangan pendidikan, semangat etos kerja Muslim puritan Persis juga terwujud dalam pengembangan ekonomi rakyat dengan didirikannya Bank Pekreditan Rakyat dan adanya sarana pengobatan gratis di Pusbankes Dhuafa sebagai sebuah bentuk kepedulian antar sesama. Hal ini sebagaimana konsepsi Max Weber tentang "innerworldy asceticism", Muslim puritan Persis mengadopsi asketisme dunia dengan tasawuf modern tanpa harus melarikan diri dari kehidupan dunia.

\section{PENUTUP}

Gerakan puritanisme Persis mulai masuk di kepulauan Sapeken sejak 1949-1967 yang dibawa oleh H. Sahwanuddi dan Ahmad Bajuri. Namun, kedua tokoh tersebut masih belum bisa memasukkan paham puritan di kalangan masyarakat kepulauan Sapeken karena paham Islam tradisional masih sangat kuat. Sehingga pada 1972 Ad-Dailamy muncul sebagai tokoh puritan yang berusaha mengubah segala bentuk tradisi yang tidak sesuai dengan al-quran dan Sunnah, dengan cara melakuakn purifikasi terhadap tradisi keagamaan Islam tradisional dan kesenian lokal. Sehingga paham puritan Persis dapat diterima oleh sebagian besar masyarakat kepulauan Sapeken bahkan Persis mampu mendirikan berbagai lembaga pendidikan. Perkembangan Persis yang demikian juga melalui berbagai tantangan baik itu berupa pertentangan ideologi maupun pententanga secara fisik. Di samping itu, hal lain yang menjadi faktor Persis dapat masuk dan berkembang di Sapeken adalah adanya etos kerja yang tinggi dari Muslim puritan Persis yang diwujudkan dalam bentuk pengembangan lembaga pendidikan dan sarana bagi kemaslahatan umat. Sikap "asketisme duniawi" Islam puritan tercermin dalam pengabdian mereka kepada agama dengan cara menumbuhkan semangat kerja yang tinggi, sebagai sebuah bentuk dari perintah dalam agama Islam yang wajib dilakukan oleh mereka sebagai hamba Allah. Dengan begitu Muslim puritan Persis melakukan berbagai usaha perdagangan seperti mendirikan toko, rumah makan, pabrik, dan tempat persewaan alat pesta untuk mendapatkan materi sebanyak yang mereka inginkan. 


\section{REFERENSI}

Badan Pusat Statistik Kabupaten Sumenep, Kabupaten Sumenep Dalam Angka Tahun 2009. Sumenep: BPS, 2009.

Baskara, Benny Islam Bajo Agama Laut. Banten: Javanica PT Kaurama Buana Antara. 2016.

Dhofier, Zamakhsyari. Tradisi Pesantren Studi Tentang Pandangan Hidup kyai. Jakarta: LP3ES,1982.

Fatimah, Nurul. "Pesantren Sebagai Basis Pengembangan Islam Puritan di kepulauan Madura (Studi Kasus Pondok Pesantren Persatuan Islam Abu Hurairah di Pulau Sapeken- Sumenep Madura)". Kurikula Jurnal Pendidikan. Fakultas Tarbiyah Institut Agama Islam Ngawi, Vol 1, No. 1, Maret 2017.

Ghazali, M. Bahri. Dakwah di kepulauan Kasus Pondok Pesantren Persatuan Islam Abu Hurairah Sapeken Sumenep. Yogyakarta: CV Amanah, 2011.

Hurairah, Ad-Dailamy Abu. Peran L-PAS Abu Hurairah Dalam Dakwah di Kepulauan. Sumenep: Pesantren Persatuan Islam Abu Hurairah, 2015.

Kristiyatno, Eddy. Reformasi dari Dalam: Sejarah Gereja Zaman Modern. Yogyakarta: Kanisius, 2004.

M Alfandi, "Prasangka Potensi Pemicu Konflik Internal Umat Islam, Walisongo, IAIN Walisongo Semarang, Vol. 21, No. 1, Mei 2013.

Noer, Deliar Gerakan Modern Islam di Indonesia 1900-1942. Jakarta: LP3ES, 1980.

Peacock. James L. Muslim Puritans: Reformist Psycology in South East Asia. Berkeley: universityof California Press, 1978.

Sutiyono. Benturan Budaya Islam: Puritan dan Sinkretis. Jakarta: Kompas, 2010.

Sukidi, "Etika Protestan Muslim Puritan: Muhammadiyah Sebagai Reformasi Islam model Protestan", Kompas, 1 Juni 2005.

Weber, Max. Etika Protestan dan Spirit Kapitalisme. TW Utomo dan Yusup Priya Sudiarja (terj.). Yogyakarta: Pustaka Pelajar, 2006.

Wildan, Dadan. Pasang Surut gerakan pembaharuan Islam di Indonesia Potret Perjalanan Sejarah Organisasi Islam (Persis). Bandung: Persis Press, 2000.

- "Pergulatan Persatuan Islam (Persis) dalam Dakwah di Tatar Sunda: Kajian Terhadap Majalah Sunda "Iber" Sebagai Media Dakwah Berbahasa Sunda". Paper dipresentasikan dalam acara Konferensi Internasional Budaya Sunda II, Revitalisasi Budaya Sunda: Peluang dan Tantangan dalam Dunia Global di Gedung Merdeka, 19-22 Desember 2011.

Wawancara dengan ustaz Ad-Dailamy Abu Hurairah, Rabu 25 April 2017.

Wawancara dengan ustaz Damin wakil ketua PC Persis Sapeken, Rabu 25 Januari 2017.

Wawancara dengan Fatmawati Rabu, 3 Mei 2017. 
Wawancara dengan ustaz Ahmad, pelatih beladiri silat Thifan Jumat, 5 Mei 2017.

wawancara dengan $\mathrm{H}$. Benu, salah satu tokoh masyarakat Sapeken, pada 30 Januari 2017.

Wawancara dengan H. Ali, Pejabat pemerintah desa dan mantan kepala desa, Rabu 1 Februari 2017. 